\title{
Colombia is Safer ... and Other Matters
}

\author{
J. Martin Ramirez*
}

Universidad Complutense Madrid, Spain

\begin{abstract}
This presentation focuses on some important general topics related to aggression and terrorism, with an special emphasis on the situation of security in Colombia. First there is an overview of the violence in Colombia, showing its recent achievements in security, with a decrease of the activity of the leftist guerrillas and the rightwing paramilitaries. But Colombia is still not safe enough due to the increase of criminal gangs, mostly purely criminal, dedicated to the cocaine trade, and lacking the ideological conviction of their forebears. Some of the more important sequels, such as the situation of millions of dispossessed are also considered, suggesting the need of an effective agrarian reform as being part of any real solution. The second part is dedicated to more general topics related to aggression and terrorism: their interactions with psychobiology, such as the psychological profile and sexual differences in terrorists or the psychological impact of the nuclear terrorism, the impact of education (school, family and mass media) and of criminal justice (from conceptual considerations on the balance between security and freedom to more specific attempts of rehabilitation of delinquents). Lastly, founded on the message of the Seville Statement on Violence proclaimed a quarter century ago, a hopeful consideration about the future is done.
\end{abstract}

Keywords: Aggression, violence, terrorism, Colombia.

\section{COLOMBIA}

One of the more important aims of any visitor is to get to know a place better and to learn from it. Colombia is a country that, as the President of the Senate of the Republic has previously reminded us, having enjoyed less that 50 years of peace and harmony during its two centuries of independence, has recovered its international prestige as one of the most serious, reliable, and future oriented nations on the South American continent. This country, that seemed to have become accustomed to living under an atmosphere of fear, has come back from the brink of destruction to feel tranquility and confidence in itself. The Colombia that you don't hear about in the newspapers is surprisingly relaxed, has a fairly stable economy and is inhabited by extremely personable and spirited people pursuing orderly lives. Even more, according to a recent Happy Planet Index (2010), which combines environmental impact with human well-being to measure the environmental efficiency with which people live long and happy lives, Colombia ranked second in the world, behind Vanuatu, where people live long and happy lives. Definitely, Colombian society has become quite mature; and their quality of life is quite good.

Unfortunately, though, we are gathered here to deal with a not so positive characteristic of today Colombia: the threat of narcoterrorism. However, from the outset it is good to point out that the Colombians are offering an example of

*Address correspondence to this author at the Pico de la Pala 6, 28792 Miraflores (Madrid) Spain; Tel: 34918444 695; Fax: 34913943 069;

E-mail: mramirez@med.ucm.es

J. Martin Ramirez, is Professor of Psychobiology at the Department of Psychobiology and Institute for Biofunctional Studies, UCM, and Visiting Fellow at Hoover Institution on War, Revolution and Peace, Stanford University. He is Chairman of CICA, and co-Chair of the $4^{\text {th }}$ CICA-STR International Conference how the threat of narcoterrorism can be tackled. Twenty years ago, when I visited Colombia on occasion of a previous CICA conference held in Santafe de Bogotá (XII CICA, 21-23 June 1990), criminal activity was bordering on what we would consider an insurgency. Powerful mafias or cartels that derive massive profits from the rich world's demand for drugs exploited the weakness of the rule of law in many parts of Latin America. The boom years of this organised crime, which began in the early 1980s, brought increased violence. During that period, on an average day one person was forcibly 'disappeared,' eight people were kidnapped, eighty were murdered and more than a thousand were forced to flee their homes (Gugliotta \& Leen, 1990). The vast amounts of money gotten through the drug trade gave the cartels significant means to sustain their enterprise -the trafficking organizations employed thousands of people from the farmer in the field to irregular troops and assassins to pilots, chemists, lawyers, and other professionals- and to protect themselves from the law. This level of influence led some to declare that Colombia was the world's first "NarcoDemocracy." (Sweeney, 1995).

In 2002, when Álvaro Uribe was first elected as Colombia's president, many of his fellow countrymen felt trapped in a never ending spiral of violence, given the complexity of a violent conflict result of the multiplicity of interests and actors involved, including the government's official forces, left-wing guerrillas since the 1960s - the Revolutionary Armed Forces of Colombia (FARC) and the much smaller National Liberation Army (ELN) - and extreme-right paramilitary groups and drug gangs since the 1980s. Army bases were being overrun by left-wing guerrillas, while right-wing paramilitaries massacred hundreds of villagers. With the economy weak as well, a steady outflow of people emigrated to escape from a country that seemed to be be- 
coming a failed state. This large-scale emigration has marked Colombian society, with roughly one of every 10 Colombians now living abroad.

Today, Colombia is back on its feet. Uribe vastly increased spending on security, transforming Colombia from a nearly failed state into a safer and more prosperous country, pursuing an aggressive "democratic security policy" aimed at expanding a state presence throughout the country, and specially in several of the formerly most conflict-ridden regions, dismantling guerrilla and paramilitary groups, eradicating coca crops, and promoting economic recovery. Nowadays Colombia is one of the most attractive emerging economies, with a fairly effective domestic police force and a witnessprotection programme. The leftist FARC and ELN guerrillas, once a mortal threat to its democracy, have been reduced to a scattered irritant. Recently, in what has been the "most resounding blow against the FARC in its entire history," in words of its new president Juan Manuel Santos (2010), an intelligence operation carefully planned a bombing raid that killed the FARC's senior military commander and chief military strategist, Víctor Julio Suárez (better known to Colombians by his nickname of Mono Jojoy). Tens of thousands of their right-wing opponents, the paramilitaries, have also been persuaded to disarm, formally at least. The violence was reduced: the murder rate halved, kidnappings and other crimes have also fallen sharply, and killings of human-rights activists and trade-union leaders abated. And, consequently, the business confidence has been restored. In contrast, in neighbouring Venezuela, since Hugo Chávez became president, in 1999, the national murder rate has risen inexorably to 75 per 100,000 people, almost twice the Colombian rate. The Venezuelan Observatory of Violence (2010) estimates the murder rate in Caracas to be an astonishing 220 per 100,000 people, higher than just about anywhere else in the world, outside war zones.

This is perhaps the highest compliment to Uribe's eightyear administration: nowadays these policies against narcoterrorism are almost taken for granted. Colombians no longer say that security is among their top worries; they are more concerned about unemployment, poverty, and health care, concerns similar to most other democratic countries. And they are passionately optimistic.

Yes, Colombia is safer, but it is still not safe enough. Despite the tangible achievements of Uribe's security policy against terrorists, his success is only relative, because the backbone of nearly half a century old insurgency is still not broken. The insurgents are adapting to military pressure resorting to guerrilla warfare tactics, coerced recruitment of new members, mostly children and youngsters, among vulnerable rural populations such as Afro-Colombians and indigenous communities, broadened involvement in drug trafficking and alliances with other illegal armed groups and drug-trafficking organisations (International Crisis Group, 2010).

Colombia has still not reached the post-conflict phase. The new Santos administration will still have to tackle a new threat: organised criminal gangs that are dedicated to the cocaine trade, from controlling coca crops to processing the paste and shipping the product. (Colombia is the world's biggest producer of cocaine, controlling 70-80 percent of total production and distribution worldwide). Officials insist that these gangs are purely criminal -simply the latest iteration of the drug trade in Colombia and lack a political agenda. They compare them to similar groups which emerged in the aftermath of civil wars in El Salvador and Guatemala. The gangs commit massacres and murders of civilians, and have "repeatedly targeted human-rights defenders, trade unionists [and] displaced persons" (Human Rights Watch, 2010). They have also been responsible for the continued eviction of civilians from rural areas they want to control. President Santos stresses that they behave as mafias (The Economist, 2011), but some human-rights groups call the bands "neoparamilitaries" and suggest that the murders of community activists, occasional indiscriminate massacres of a dozen or more villagers, and land evictions are designed to exert social and political control over territory, just as the former paramilitaries used to do. Although security policy has vastly improved -on Christmas day 2010, the police carried out a raid where probably the most cruel narco capo, a former leader of the para Centauros, Pedro Oliverio Guerrero, alias El Cuchillo (the Knife), was killed-, peace and security are still threatened by the onslaught of the drug-trafficking organizations.

The new gangs appear to lack the ideological conviction of their forebears, although they have sought alliances of convenience with the FARC and the ELN. They do, however, remain better armed than ordinary criminals. The government has seized more than 6,000 Chinese-made rifles from these gangs over the past two years. These drug gangs may not yet be a direct threat to national security. But Santos admits that security policy needs to be adapted to these new threats. Rather than deploying military bombardments against them, the new bands must be fought "with intelligence, like other criminal organisations," he says. He argues that just as special army units were trained to fight the FARC in the jungle, special police units are needed to combat crime in the cities, where murder rates have gone up in the past years. A pillar of this policy would be the improving of tools available to the justice system and security forces to catch, prosecute and jail the perpetrators of crime, including a change in juvenile criminal law to prosecute young offenders, as well as the fomenting of urban culture, education and sports to improve the sense of solidarity (Alsema, 2010). Protecting Colombia's economic and security turnaround will require constant vigilance and innovation.

Another horrible consequence of the terrorism Colombia has experienced and that has not yet been eradicated is its involuntary protagonists, the victims. Last year, the Spanish Crown Prince, Felipe de Borbón, in his opening words to the 5th Congress of Victims of Terrorism held in Medellín (2009), spoke of "how the intensity of the pain generated by years of terrorist violence became an indelible imprint on so many thousands of Colombian people and families" while, at the same time, "we also feel a strong hope reflected in a constant struggle against it, in an advance towards its definitive eradication." "Terrorism," Prince Felipe has also said on another occasion, "is one of the most brittle expressions of totalitarism, hate, and intolerance... It is quite inhumane, cowardly and always unjustifiable, because it is directed against the most elemental of human rights: life, freedom, and physical or moral integrity. Moreover," he concluded, "it destroys families and leaves brutal consequences. It is the biggest enemy of democracy and peace." 
There is also a phenomenon specific to Colombian political violence -namely large numbers of internally displaced people (desplazados internos) (IDPs), defined by United Nations as "persons who have been forced to flee their homes as a result of armed conflicts, situations of generalized violence, violations of human rights, natural or humanmade disasters, and who have not crossed an internationally recognized State border" (10). Though estimates varied, studies agree that the displacement of peasants by armed groups in Colombia is pan-national and on the rise (Latin America News Dispatch, 2011). According to SISDESC (System of Information on the Families Displaced by Violence in Colombia), in 1997 every two hours, two families were displaced by violence in the country; all together, more than 900,000 people had been internally displaced by the violence between the leftist guerillas and government forces. By 1999, estimates of the number of IDPs ranged between 450,000 and 1.6 million. On 8 November 2010, just when this CICA-STR Conference is taking place, the United Nations says that Colombia counts 3.7 million IDPs, i.e., people who claim to have lost their land when they fled, and are now officially registered as internally displaced by paramilitaries and guerrillas (UNHCR, 2010; Colombia Reports, 2010). According to other sources this number is even higher: the United Nations High Commissioner for Human Rights (CODHES, standing in Spanish for Consultoría para los Derechos Humanos y el Desplazamiento) stated that in 2005 IDPs had climbed dramatically to 3'5 millions, it was reaching 4.9 million at the end of 2009 , and the latest numbers cite Colombia as having a total of 5.2 million displaced people (Hieden, 2011).

Finally, another important chronic problem in this country has to do with agrarian reform. Extremely unequal land ownership is both a cause and a consequence of the political conflicts that have plagued Colombia for so many decades. According to official figures, in 1984, 32 percent of the land was in the hands of just 0.55 percent of landowners, while 85 percent of the country's farmers had less than 15 percent of the land. Over the following twenty years, the imbalance grew. The number of large landowners shrunk while the land in their possession expanded: by 2003, 0.4 percent of landholders had 63.6 percent of the country's farmland, while the proportion of small farmers rose to 86.3 percent, and their share of land plunged to 8.8 percent (Restrepo, 2010). Over the past three decades between $3.5 \mathrm{~m}$ and $6 \mathrm{~m}$ hectares of farmland have been seized by drug traffickers and paramilitaries (often the same people) in part to wrest territory from the left-wing guerrillas, and in part to launder their profits in what amounted to a violent and illegal agrarian "counterreform".

A quick look at the history shows that previous government policies have always failed to modify the land ownership structure. It appeared to be over when Alfonso López Pumarejo passed an agrarian reform law in 1936, which stated that private property had a social function to fulfill, and authorised the state to expropriate idle land. The law did not, however, actually manage to modify the structure of rural property. Decades of violence stimulated a 1961 land reform, and an agrarian programme was the banner waved by the leftist guerrillas since then: by Manuel Marulanda (the leader of the FARC, better known as Tirofijo) to win thousands of campesinos over to the armed uprising of the 1960s, and by Father Camilo Torres, at the emergence of the ELN, the second-biggest rebel group. In 1968 Carlos Lleras Restrepo pushed through an agrarian reform programme that was cut short in 1973, under the government of Misael Pastrana, by the Chicoral Pact, an agreement between the traditional parties and the terratenientes or wealthy landowners that put an end to land redistribution efforts. And the mass displacement of peasant farmers over the past two decades, forced off their land by violence, threats or deception, has further aggravated the situation. In theory, when paramilitaries demobilised under Uribe, they were supposed to turn over this land, but only 17,000 hectares among the estimated 4 million hectares bought with ill-gotten money were surrendered.

The new government is trying to reverse the violent agrarian "counter-reform," even if they are careful to avoid calling the new effort a land reform, because it was a policy that failed in the past. In September 2010 a bill on "land restitution" was published to create special courts to oversee land restitution, seizing land stolen by the mafias and returning it to its original owners. The Court would require the current landowners to show they acquired land legally and without violence or threats. The broader aim is to formalise land tenure in a country where only 40 percent of farms have titles and only half have been valued. It will not be easy, because some 70 percent of displaced people hold no formal title, and many worked the land for generations under unwritten share cropping arrangements. The most difficult part of this complex, obstacle-strewn process is perhaps guaranteeing the safety of campesinos who dare to return despite the threats from new "owners" who back their shady claims to ownership with weapons, as it is illustrated by the following story which happened quite recently not far from Cartagena de Indias. In San Onofre, near the Montes de Maria, there is a farm of 550 hectares called La Alemania. In 1998, a group of 52 families joined together and, with the help of government land-reform grants and soft loans, purchased the farm. Just two years later they were run off the land by a squad of illegal, right-wing paramilitaries who set up camp on their land. Pressed at gunpoint to sell, the farmers fled to nearby towns. Six of them were killed. In 2006, after the paramilitaries demobilised and their leader was himself killed, the farmers dared to return. Their 600 cattle had been sold, pasture was overgrown and cropland neglected. A creditor bank was about to auction off the farm to cover an unpaid debt of 1.6 billion pesos $(\$ 900,000)$. The collective's president was shot dead in May 2010 by half a dozen men. Two women from the Montes de Maria are attending our conference with the purpose of informing the participants about their personal experiences there. But they are not the only ones facing similar afflictions in their quest to recover their land. Some landowners made forced sales after being told "either you sell to me or your widow will." Others abandoned their plots (The Economist, 2010). The government, thus, will also have to try to protect those who make claims.

Many believe that returning their land to some four-five million peasants displaced by the war is an impossible mission because the experience of years says that any attempt at modifying the land ownership structure in Colombia has lead to violence: in the places where the greatest efforts are made to restore property to the original owners, there is more vio- 
lence, and the threats are constant. This can be expected to face violent resistance as well as a rearguard action in the courts. But, despite the enormous difficulties it faces, there are two reasons that make this policy one of the top priorities of Santos' administration: agrarian reform is not only an essential factor for economic growth and development but, what is even more important, it is a sine qua non for the success of any peace programme (16). Even if Juan Manuel Santos only achieves half of what it sets out to, it will amount to a revolution in rural Colombia.

\section{OTHER MATTERS}

Obviously, a congress such as this 4th Annual CICA/ STR International Conference, with attendees from four continents, has to consider other topics related to aggression, violence, and terrorism, at more global levels too. To what extent does human biology influence these behaviors? What is the impact of education through school and mass media? What role does the criminal justice system play, from conceptual considerations in the balance between security and freedom to a more specific impact of rehabilitation of juvenile and adult offenders (see: Walters, Ramírez, \& Bettin, in press).

An important consideration in the study of international terrorism is the reality that terrorist violence does not stay within the borders of a target or host country. Modern day terrorism has a cross-national character; it is a global phenomenon. And this requires an international coordination of solutions. No country can feel free of the threat of terrorist attacks or of their consequences; consequently, no country can avoid a commitment for sharing in the efforts and risks of fighting terrorism. And, even more, a minimally responsible government is not allowed to show any complicity gesture towards terrorists as, according to some sources, another Bolivarian country seems to be doing. Since 2002, the Spanish Security is detecting a migratory trend of etarras (member of the Spanish terrorist group ETA) from Mexico to Venezuela; for instance, it has been recently reported ( $L a$ Vanguardia, 7 Oct 2010) that two Spanish terrorists confessed that they went to Venezuela, with two mapuches (indigenous inhabitants of Chile) to attend a workshop on the use of weapons and how to manipulate explosive substances. All countries, thus, must fulfill their international responsibilities, in part by not allowing the use of their lands for terrorist groups, narcotrafficking or organized crimes. Even Gaddafi's Libya has learned that you cannot play with this kind of fire! ${ }^{1}$

\footnotetext{
${ }^{1}$ A quarter of a century ago, his diplomats shot a British policewoman, his agents bombed a nightclub in Berlin, and his secret service started to bring down airliners, such as their Lockerbie attack. The ostracism of the the West in the 1990s failed to shift Muammar Gaddafi from power, but it did help persuade him to make concessions, such as giving up his nuclear programme and helping to blow the lid on the nuclear black market centred on Pakistan, as well as stopping the sponsorship of terrorism and, very specifically, paying $\$ 10$ million to the families of each of the Lockerbie victims. The most notable of his bilateral agreements was the "Friendship Pact" signed with Italy on August 30th, 2008. The two countries pledged increase cooperation in "fighting terrorism, organized crime, drug trafficking, and illegal immigration." Gaddafi agreed to keep African migrants from leaving its frontiers for Italy, and readmit to Libya those intercepted in international waters. The price tag for this service was $\$ 5$ billion Italian investment, and six patrol boats to police the waterways between Africa and Europe (Yahmaian, 2011). And in 2009, he was even invited at a G8 summit in L'Aquila, to talk about world trade and food security with prime ministers and presidents.
}

Another relevant and important topic of the conference is the role of psychobiology in violence and terrorism. An analysis of this role will address the biological sexual differences found in the threat of violence or suicide; the mental profile of terrorists and suicide bombers, and the psychological impact of a nuclear threat or of the more probable threat of biological attack. Even if we cannot close our eyes to the threat of a nuclear war, it is even more probable and closer in time that we will face the danger of massive destruction by the virulent small pox, influenza, or other contaminant plagues. I do not think it is far from reality to stress the urgent need to develop appropriate protection against biological weapons that are being developed or, even worst, already available.

The presence of violence within the family, in schools, and in the social media, and more specifically in videogames, will also be discussed during the conference. Of note, while discussing terrorism, Iñigo Lamarca, ararteko (ombudman) of the Basque country, said: "Youth are learning to hate. The justification of ETA is born within the family. It is at home where one learns everything; schools have only a complementary role. If we want to educate for peace, therefore, it has to start in each of our homes." (Euskadiko Herriaren Defendatzailea, 2009).

Justice is a word that must always be present in discussions of the phenomenon of terrorism, in discussions of ways to eliminate related problems (such as leyes de punto final or amnesties), and in discussions of impunity. Nobody is above the law, a concept rightly defended by the Attorney General of the Colombian Republic during his presentation for this conference. The legal system will not give in to blackmail not even an inch- because showing weakness in front of terrorists increases the chances of new attacks. Lack of impunity suggests a moral leveling between victims and tyrants, as if we all were victims, and there are no tyrants, as if the terrorist were patriots, activists, or even freedom fighters, instead of what they really are -delinquent and criminal. It is thus quite interesting to assess the value that criminal law brings to the assessment of terrorism as a crime with political purpose, an act of political violence, but not as a political offense (Gómez Bermúdez, 2010).

And of course, a call to human rights cannot be absent when analyzing potential abuses made under the excuse of a terrorist threat. For instance, taking advantage of the anxiety experienced within the population by a terrorist attack, one may want to justify the adoption of exceptional measures. These measures occasionally reduce in a too exorbitant way the rights of the citizens, diminishing or even fully avoiding fundamental guarantees. We must make it quite clear that this attitude subverts the rule of law in the name of security, using Orwellian euphemisms such as control orders (instead of a house arrest without trial), extraordinary rendition (instead of kidnapping), and enhanced interrogation techniques (which are nothing less than torture). As Benjamin Franklin said: "He who would put security before liberty deserves neither".

Finally, conference participants will discuss promising programs for reducing chronic violence, for the re-education of juvenile delinquents, and for the deradicalization of terrorists (START \& ICSR, 2010). These ideas may have political implications for our host country in reeducating former guer- 
rilla fighters, and for any other country that is working to change the hearts and minds of those engaged in political violence.

During this conference we are going to deal about all these things, and more.

These days of solid reflection on the control of violence, the end of terrorism, and the consolidation of justice and peace, I am sure, would lead us towards hope of a better world. This hope is founded on the message of the Seville Statement on Violence proclaimed a quarter century ago during an earlier CICA Conference held in my at that time alma mater, Seville (VII CICA, 10-18 May 1986), and endorsed three years later by the General Conference of UNESCO in Paris. His Holiness the Dalai Lama reiterated the importance of this Statement when he wrote:

"Over the past two or three decades, there have been literally hundreds of scientific studies indicating that aggression is not essentially innate and that violent behavior is influenced by a variety of biological, social, situational, and environmental factors. Perhaps the most comprehensive statement on the latest research was summarized in the 1986 Seville Statement on Violence that was drawn up and signed by twenty top scientists from around the world. In that statement, they of course acknowledged that violent behavior does occur, but they categorically stated that it is scientifically incorrect to say that we have an inherited tendency to make war or act violently. That behavior is not genetically programmed into human nature. They said that even though we have the neural apparatus to act violently, that behavior isn't automatically activated. There's nothing in our neurophysiology that compels us to act violently. In examining the subject of human nature, most researchers in the field currently feel that fundamentally we have the potential to develop into gentle, caring people or violent, aggressive people; the impulse that gets emphasized is largely a matter of training." (1998, p. 58)

\section{DISCLOSER}

Introductory words at the opening session of the 4th CICA/STR International Conference, Cartagena de Indias, Colombia, 18-20 November 2010.

\section{ACKNOWLEDGEMENT}

None.

\section{CONFLICT OF INTEREST}

None.

\section{REFERENCES}

Alsema, A. (2010). Colombia to invest \$2B in urban security. Colombia Reports, 4 October 2010.

Borbón, F. de, (2009). Opening Words, 5th Congress of Victims of Terrorism, Medellín (Colombia), 29 May 2009.

Colombia Reports (2010). Colombia has most displaced in world: UN. Colombia Reports, 9 November 2010.

Consultoría para los Derechos Humanos y el Desplazamiento. (2005). El Desplazamiento en Cifras. Codhes Informa, 55. December 2005, Bogota: Codhes.

Dalai Lama \&. Cutler, H.C. (1998). The Art of Happiness: A Handbook for Living, USA, Riverhead Books,

Euskadiko Herriaren Defendatzailea (2009). Eusko Legebilt-zarrarentzako txostena 2009 (Report to the Basque Parlament 2009), Vitoria: Eusko Legebiltzarrak.

Gómez Bermúdez, J. (2010). No destruirán nuestra libertad, Madrid: Temas de Hoy, Gugliotta, G., \& Leen, J., Eds. (1990). Kings of Cocaine. Miami: Miami Herald Series.

Hieden, T. (2011). 1/3 of displaced people in 2010 moved from 'consolidated areas' Colombia Reports, 16 February 2011.

(a) Happy Planet, (2010). Happy Planet Index 2.0 report 2010, Retrieved November 20, 2010, from http://www.happyplane-tindex.org

(b) Human Rights Watch, (2010). 20th Annual World Report, Retrieved November 20, 2010, from http://www.hrw.org/world-report-2010

(c) International Crisis Group (2010). Improving Security Policy in Colombia, Latin America Briefing $\mathrm{N}^{\circ} 23,29$ June 2010.

Latin America Briefing (2010). Improving Security Policy in Colombia, Latin America Briefing 2329, 10, June 2010.

Latin America News Dispatch (2011). Colombian peasants continue to suffer displacement due to war, Latin America News Dispatch, 22 February, 2011

La Vanguardia (2010). España busca nexos FARC-ETA en Colombia, $L a$ Vanguardia, 7 October 2010.

Neumann, P.R. (2010). Prisons and Terrorism: Radicalization and Deradicalization in 15 Countries, ICSR \& START, London: King's College.

Restrepo, J.D. (2010). Land Reform, a Top Priority of New Colombian Government. IPS (Inter Press Service), Bogota, 4 October 2010.

Santos, J.M. (2010). Presidente Santos confirma la muerte del Mono Jojoy y otros cabecillas, available at: radiosantafe.com, 23 September 2010.

Sweeney, J., (1995). Colombia's Narco-Democracy Threatens Hemispheric Security. The Heritage Foundation, 1-2., 21 March 1995.

The Economist (2010). This land is our land, The Economist, 16 September 2010.

The Economist (2011). Securityin Colombia. New names, old games. The Economist, 28 April 2010.

United Nations High Commission on Human Rights (1998). Guiding Principles on Internal Displacement, Geneva: UNHCR.

United Nations High Commission for Refugees UNHCR refugee statistics, (2010). Global Report 2010. Geneva: UNHCR.

Venezuelan Observatory of Violence (2010). Noticias sobre violencia en Venezuela, Retrieved November 20, 2010, from $<$ http://www.observatoriodeviolencia.org.ve>

Walters, T.K., Ramírez, J. M. \& Bettin, M., (in press). $4^{\text {th }}$ CICA/ STR International Conference on Aggression, Political Violence and Terrorism: An Interdisciplinary Approach for a Peaceful Society. Behavioral Sciences on Terrorism and Violence.

Yahmaian, B. (2011). Why Europe Fears the North African Uprisings: The Spectre of a Black Europe. 23 February, 2011, Retrieved February 23, 2011 from http://www.counterpunch.org/ behzad02232011.html 